\title{
The number and microlocalization of
} tumor-associated immune cells are associated with
patient's survival time in non-small cell lung cancer

Fuqiang Dai1,2, Lunxu Liu¹, Guowei Che1, Nanbin Yu13,3, Qiang Pu1', Shangfu Zhang ${ }^{1}$, Junliang Ma1', Lin Ma1 and Zongbing You*4

\begin{abstract}
Background: Tumor microenvironment is composed of tumor cells, fibroblasts, endothelial cells, and infiltrating immune cells. Tumor-associated immune cells may inhibit or promote tumor growth and progression. This study was conducted to determine whether the number and microlocalization of macrophages, mature dendritic cells and cytotoxic T cells in non-small cell lung cancer are associated with patient's survival time.

Methods: Ninety-nine patients with non-small cell lung cancer (NSCLC) were included in this retrospective study. Paraffin-embedded NSCLC specimens and their clinicopathological data including up to 8-year follow-up information were used. Immunohistochemical staining for CD68 (marker for macrophages), CD83 (marker for mature dendritic cells), and CD8 (marker for cytotoxic T cells) was performed and evaluated in a blinded fashion. The numbers of immune cells in tumor islets and stroma, tumor islets, or tumor stroma were counted under a microscope. Correlation of the cell numbers and patient's survival time was analyzed using the Statistical Package for the Social Sciences (version 13.0).

Results: The numbers of macrophages, mature dendritic cells and cytotoxic T cells were significantly more in the tumor stroma than in the tumor islets. The number of macrophages in the tumor islets was positively associated with patient's survival time, whereas the number of macrophages in the tumor stroma was negatively associated with patient's survival time in both univariate and multivariate analyses. The number of mature dendritic cells in the tumor islets and stroma, tumor islets only, or tumor stroma only was positively associated with patient's survival time in a univariate analysis but not in a multivariate analysis. The number of cytotoxic T cells in the tumor islets and stroma was positively associated with patient's survival time in a univariate analysis but not in a multivariate analysis. The number of cytotoxic T cells in the tumor islets only or stroma only was not associated with patient's survival time.

Conclusions: The number of macrophages in the tumor islets or stroma is an independent predictor of survival time in NSCLC patients. Counting macrophages in the tumor islets or stroma is more useful in predicting patient's survival time than counting mature dendritic cells or cytotoxic T cells.
\end{abstract}

\section{Background}

Tumor microenvironment is composed of tumor cells, resident cells such as fibroblasts and endothelial cells, and infiltrating cells such as macrophages, dendritic cells, and

\footnotetext{
*Correspondence: lunxu_liu@yahoo.com.cn, zyou@tulane.edu

1 Department of Thoracic and Cardiovascular Surgery, West China Hospital, Sichuan University, Chengdu 610041, China

4 Departments of Structural \& Cellular Biology and Orthopaedic Surgery, Tulane Cancer Center, LCRC, Tulane Center for Aging, Tulane Center for Gene Therapy, Tulane University School of Medicine, New Orleans, LA 70112, USA Full list of author information is available at the end of the article
}

lymphocytes, as well as products of all these cells such as extracellular matrix, growth factors, cytokines, chemokines, enzymes, and various metabolites [1]. The crosstalk between tumor cells and other tumor-associated cells may lead to either blocking tumor formation or enhancing tumor formation and/or progression. The doubleedged-sword nature of many tumor-associated immune cells such as macrophages, dendritic cells, and cytotoxic $\mathrm{T}$ cells has been recognized [2-4]. On the one hand, these immune cells may recognize tumor-associated antigen 
and activate cytotoxic $\mathrm{T}$ cells, in order to initiate antitumor immune responses. On the other hand, the same immune cells may establish immune tolerance and even promote tumor growth and metastasis through enhancing angiogenesis and invasion of extracellular matrix.

Non-small cell lung cancer (NSCLC) is the most common cause of cancer-related death worldwide. The fiveyear survival rate is approximately $67 \%$ for the patients with stage IA NSCLC after putatively curative surgery [5]. In order to identify new prognostic factors that can guide clinical practice, we have previously found that the number of tumor-associated macrophages (TAMs) in the tumor islets is positively associated with survival time in the patients with NSCLC [6]. Because TAMs are not the only tumor-associated immune cells, in this study we further investigated the prognostic value of mature dendritic cells and cytotoxic T cells in the patients with NSCLC.

\section{Methods}

\section{Study population}

This study was approved by the Institutional Review Board of West China Hospital, Sichuan University. The procedures to obtain human lung cancer tissues and follow-up information are in accordance with the Ethical Principles for Medical Research Involving Human Subjects as formulated in the World Medical Association Declaration of Helsinki (revised in 2008). All specimens were obtained from the archives of formalin-fixed, paraffin-embedded tissue blocks in the Department of Thoracic and Cardiovascular Surgery, West China Hospital, Sichuan University. The lung cancer tissues were collected from surgeries performed from August, 1999 to August, 2001. The patients were followed up until December, 2007, through outpatient visits and/or correspondences to family members. Ninety-nine patients were included in this retrospective study. Histological evaluation was based on the World Health Organization criteria [7]. Tumor stage was evaluated according to the International Union against Cancer TNM classification system [7]. The clinicopathological characteristics were summarized in Table 1.

\section{Immunohistochemistry}

Four- $\mu \mathrm{m}$ thick tissue sections were de-waxed in xylene and rehydrated through graded alcohols. Antigen retrieval was carried out using microwave at middle-tohigh temperature for $8 \mathrm{~min}$, low-to-high temperature for $5 \mathrm{~min}$, and then cooled down at room temperature for 20 min. Mouse anti-human CD68 monoclonal antibodies (clone KP1, recognizing macrophages), rabbit antihuman CD8 monoclonal antibodies (clone SP16, recognizing cytotoxic $\mathrm{T}$ cells), and streptavidin-peroxidase conjugated secondary antibodies (SP-9002) were obtained from Zhongshan Goldenbridge Biotechnology Co., LTD., Beijing, China. Mouse anti-human CD83 monoclonal antibodies (clone $\mathrm{HB15a}$, recognizing mature dendritic cells) were obtained from Santa Cruz Biotechnology, Inc., Santa Cruz, CA, USA. Diaminobenzidine (DAB) substrate kit was obtained from Dako North America, Inc., Carpinteria, CA, USA. Immunohistochemical staining of individual markers was performed according to the kit manufacturer's instructions. Sections were then counterstained with hematoxylin and mounted in an aqueous mounting medium. Tissue sections previously stained positively were used as positive control, while tissue sections with primary antibodies replaced by phosphate-buffered saline served as negative control. Positive cells showed brown particles on the cellular membrane and/or in the cytoplasm. Under a microscope, five representative high-power fields ( $\times 400$ magnification) of the tumor islets and stroma per tissue section were selected and counted for positive cell numbers. The average number of these five high-power fields represented the cell number per high-power field. Evaluation of the stained tissue sections was performed by two investigators who were blinded in regard to the clinicopathological characteristics. An average of the results obtained by the two examiners was used to represent each case.

\section{Statistical analysis}

Statistical analysis was carried out using the Statistical Package for the Social Sciences (SPSS, version 13.0, SPSS Inc., Chicago, IL, USA). For categorical analysis, the median number of cells per high-power field was used as a cut-off point to dichotomize the continuous variables. The Mann-Whitney nonparametric test was used to compare between two groups. In order to assess any potential relationship between the number of immune cells and patient's survival time, the Spearman's rank correlation coefficient (Spearman's rho, or $r_{s}$ ) was calculated in a univariate analysis. The correlation between the number of immune cells and the clinicopathological characteristics was analyzed using the $\chi^{2}$ test. The Kaplan-Meier survival curves were used to look for correlation between the cell number and patient's survival time, or between the ratio of cells in the tumor islets versus stroma and patient's survival time. Statistical significance was analyzed using the log-rank test. A multivariate Cox proportional hazards model was used to estimate adjusted hazard ratios and $95 \%$ confidence intervals (CI) and to identify which variable was an independent prognostic factor. The validity of the proportional hazards assumption was assessed from $\log (-\log$ [Survival]) curves. For the above comparisons, $\mathrm{P}<0.05$ was considered statistically significant. 
Table 1: Clinicopathological characteristics of patients with non-small cell lung cancer $(\mathbf{n}=99)$

\begin{tabular}{|c|c|c|}
\hline Variable & $\mathrm{N}=99$ & 5-yr survival (\%) \\
\hline Age years median (range) & $60(37-80)$ & Overall \\
\hline Gender (male: female) & $80: 19$ & 32 \\
\hline \multicolumn{3}{|l|}{ Tumor stage: } \\
\hline I & 35 & 49 \\
\hline ॥ & 20 & 35 \\
\hline III & 34 & 19 \\
\hline IV & 10 & 10 \\
\hline \multicolumn{3}{|l|}{ Histology } \\
\hline Adenocarcinoma & 45 & 22 \\
\hline Squamous cell carcinoma & 51 & 41 \\
\hline Large cell carcinoma & 3 & 33 \\
\hline \multicolumn{3}{|l|}{ Tumor grade } \\
\hline Well differentiation & 3 & 67 \\
\hline Moderate differentiation & 48 & 40 \\
\hline Poor differentiation & 29 & 24 \\
\hline Not recorded & 19 & 20 \\
\hline \multicolumn{3}{|l|}{ Lymph node metastasis } \\
\hline No & 59 & 44 \\
\hline Yes & 40 & 15 \\
\hline
\end{tabular}

Histological criteria for the tumor grading:

Adenocarcinomas:

Well differentiation: glandular lumens are large and similar in sizes, with less cytologic atypia.

Moderate differentiation: glandular lumens vary in sizes, with obvious cytologic atypia.

Poor differentiation: glandular lumens are small or absent, with obvious cytologic atypia and mitosis.

Squamous cell carcinomas:

Well differentiation: $\geq 20 \%$ of the tumor islets has pearl formation.

Moderate differentiation: $<20 \%$ of the tumor islets has pearl formation.

Poor differentiation: no pearl formation in the tumor islets; only shows intracellular keratinization.

Large cell carcinomas: by definition, are poorly differentiated tumors that lack the cytologic and architectural features of small cell carcinoma,

squamous cell carcinoma, or adenocarcinoma.

\section{Results}

\section{Patient characteristics}

All of the 99 patients (Table 1) had complete follow-up information and the pathological diagnosis was verified by a pathologist prior to inclusion in this study. The overall cumulative 5-year survival rate was $32 \%$. Patients with stage I carcinomas, squamous cell carcinomas, well-differentiated carcinomas, or carcinomas without lymph node metastasis had better survival rates than the other patients (Table 1 ).

\section{Immunohistochemical detection of the tumor-associated immune cells}

Macrophages, mature dendritic cells, and cytotoxic $\mathrm{T}$ cells were detected by anti-CD68 antibodies, anti-CD83 antibodies, and anti-CD8 antibodies, respectively (Figure 1 ). These tumor-associated immune cells were located in both the tumor islets and stroma. Under each high-power field ( $\times 400$ magnification), the median number of macrophages in the tumor islets and stroma is approximately 15 (Table 2). The median number of macrophages in the tumor islets only is approximately 4 . The median number of macrophages in the tumor stroma only is approximately 7 , which was significantly more than that in the tumor islets $(\mathrm{P}=0.040)$. The median numbers of mature dendritic cells in the tumor islets and stroma, tumor islets only, or tumor stroma only were approximately 13,4 , or 7 , respectively (Table 2). The number of mature dendritic cells in the tumor stroma was significantly more than that in the tumor islets $(\mathrm{P}=0.000)$. The median numbers of CD8+ cytotoxic $\mathrm{T}$ cells in the tumor islets and stroma, tumor islets only, or tumor stroma only were approximately 11,4 , or 7 , respectively (Table 2 ). The number of 
Table 2: Correlation between the number and microlocalization of immune cells and patient's survival time by a univariate analysis

\begin{tabular}{|c|c|c|c|c|c|c|c|}
\hline \multirow[t]{2}{*}{ Cell type } & \multicolumn{2}{|c|}{ Islets + Stroma } & \multicolumn{2}{|c|}{ Islets } & \multicolumn{2}{|c|}{ Stroma } & \multirow{2}{*}{$\begin{array}{l}P \text { (islets } \\
\text { versus } \\
\text { stroma) }\end{array}$} \\
\hline & Number & $\begin{array}{l}\text { Spearman' } \\
\text { s rho \& P }\end{array}$ & Number & $\begin{array}{l}\text { Spearman' } \\
\text { s rho \& P }\end{array}$ & Number & $\begin{array}{l}\text { Spearman' } \\
\text { s rho \& P }\end{array}$ & \\
\hline Macrophages & $\begin{array}{l}15.2 \\
(1.8-48.4)\end{array}$ & $\begin{array}{l}r_{s}=-0.105 \\
P=0.300\end{array}$ & $\begin{array}{l}4.2 \\
(0.2-40.6)\end{array}$ & $\begin{array}{l}r_{s}=0.483 \\
P=0.000\end{array}$ & $\begin{array}{l}7.2 \\
(0.4-39.6)\end{array}$ & $\begin{array}{l}r_{s}=-0.541 \\
P=0.000\end{array}$ & 0.040 \\
\hline $\begin{array}{l}\text { Mature } \\
\text { dendritic cells }\end{array}$ & $\begin{array}{l}13.2 \\
(1.4-137.6)\end{array}$ & $\begin{array}{l}r_{s}=0.221 \\
P=0.028\end{array}$ & $\begin{array}{l}4.2 \\
(0-21.4)\end{array}$ & $\begin{array}{l}r_{s}=0.404 \\
P=0.001\end{array}$ & $\begin{array}{l}7.0 \\
(0.2-25.4)\end{array}$ & $\begin{array}{l}r_{s}=0.284 \\
P=0.045\end{array}$ & 0.000 \\
\hline CD8+ T cells & $\begin{array}{l}10.8 \\
(0.4-45.0)\end{array}$ & $\begin{array}{l}r_{s}=0.297 \\
P=0.003\end{array}$ & $\begin{array}{l}4.2 \\
(0-66.2)\end{array}$ & $\begin{array}{l}r_{s}=0.247 \\
P=0.014\end{array}$ & $\begin{array}{l}7.2 \\
(0.2-71.4)\end{array}$ & $\begin{array}{l}r_{s}=0.212 \\
P=0.035\end{array}$ & 0.032 \\
\hline
\end{tabular}

The number of immune cells represents median (range) per high-power field. The number of immune cells in the tumor islets and stroma (Islets + Stroma) was obtained by combining the number in the tumor islets and the number in the tumor stroma in each case. Then, the numbers of immune cells in the tumor islets and stroma were ranked and the median number was determined. Therefore, the median number of immune cells in the tumor islets and stroma is not a simple sum of the median number in the tumor islets and the median number in the tumor stroma as shown in this table.

CD8+ cytotoxic T cells in the tumor stroma was significantly more than that in the tumor islets $(\mathrm{P}=0.032)$.

\section{Correlation between the number and microlocalization of immune cells and survival time}

The Spearman's rank correlation coefficient (Spearman's rho, or $r_{s}$ ) was calculated to assess any potential relationship between the tumor-associated immune cells and patient's survival time. We found that the macrophage number in the tumor islets and stroma had no association with patient's survival time $\left(\mathrm{r}_{\mathrm{s}}=-0.105, \mathrm{P}=0.300\right)$. The macrophage number in the tumor islets was positively associated with patient's survival $\left(\mathrm{r}_{\mathrm{s}}=0.483, \mathrm{P}=0.000\right)$. In contrast, the macrophage number in the tumor stroma was negatively associated with patient's survival $\left(r_{s}=\right.$ -
$0.541, \mathrm{P}=0.000$ ) (Table 2). The numbers of mature dendritic cells in the tumor islets and stroma, tumor islets, and tumor stroma were all positively associated with patient's survival time, with $r_{s}=0.221(P=0.028), 0.404$ $(P=0.001)$, and 0.284 $(P=0.045)$, respectively. Similarly, the numbers of CD8+ cytotoxic T cells in the tumor islets and stroma, tumor islets, and tumor stroma were also positively associated with patient's survival time, with $\mathrm{r}_{\mathrm{s}}=$ $0.297(\mathrm{P}=0.003), 0.247(\mathrm{P}=0.014)$, and $0.212(\mathrm{P}=0.035)$, respectively (Table 2 ).

In order to assess whether there is any value in predicting prognosis, the median number of the tumor-associated immune cells was used as a cut-off point to dichotomize the 99 patients into a group with a cell number above the median and a group with a cell number
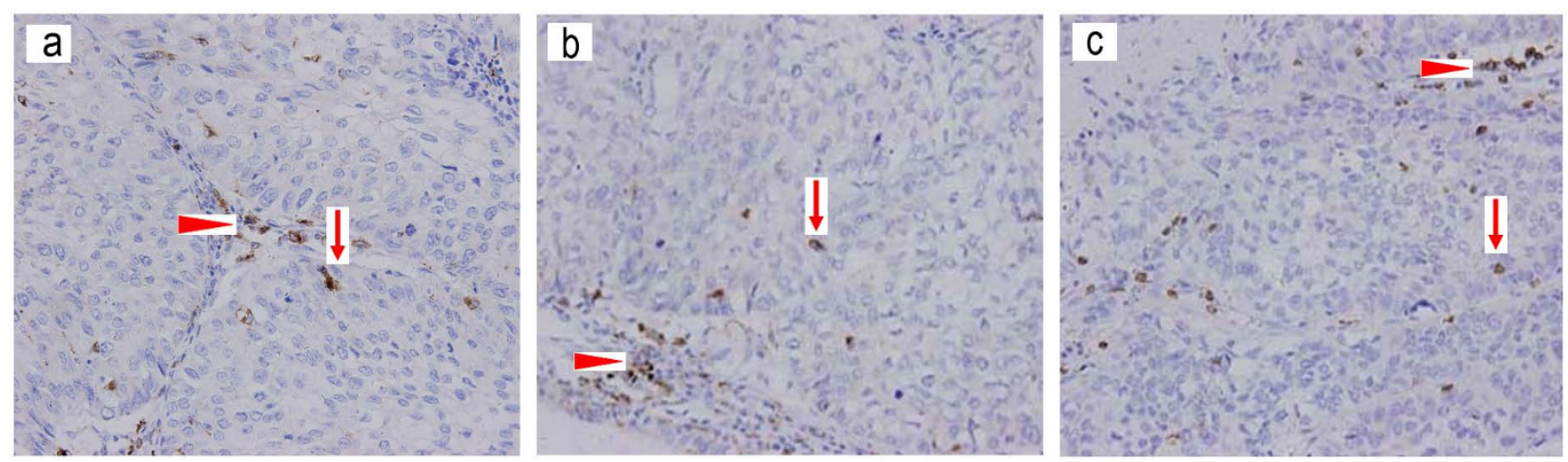

Figure 1 Immunohistochemical detection of tumor-associated immune cells in non-small cell lung cancer tissues. (a) Macrophages (marker CD68) stained brown in the tumor islets (arrow) and tumor stroma (arrowhead). (b) Mature dendritic cells (marker CD83) stained brown in the tumor islets (arrow) and tumor stroma (arrowhead). (c) Cytotoxic T cells (marker CD8) stained brown in the tumor islets (arrow) and tumor stroma (arrowhead). Original magnification, $\times 400$. 
below the median. We found that the patients with above-the-median macrophage number in the tumor islets and stroma had a similar Kaplan-Meier survival curve, compared to those patients with below-themedian macrophage number in the tumor islets and stroma ( $\mathrm{P}=0.322$, Figure $2 \mathrm{a})$. The patients with abovethe-median macrophage number in the tumor islets had a significantly better cumulative survival, compared to the patients with below-the-median macrophage number in the tumor islets $(P=0.001$, Figure $2 b)$. In contrast, the patients with above-the-median macrophage number in the tumor stroma had a significantly worse cumulative survival, compared to the patients with below-themedian macrophage number in the tumor stroma $(\mathrm{P}=$ 0.000 , Figure $2 \mathrm{c}$ ). When the ratio of the macrophage number in the tumor islets versus the macrophage number in the tumor stroma was calculated, the patients with above-the-median ratio (islets/stroma) had a significantly better cumulative survival, compared to the patients with below-the-median ratio $(P=0.000$, Figure $2 \mathrm{~d})$.

The patients with above-the-median numbers of mature dendritic cells in the tumor islets and stroma, tumor islets, and tumor stroma had a significantly better cumulative survival, compared to the patients with below-the-median numbers of mature dendritic cells $(\mathrm{P}=$ $0.000,0.005$, and 0.019, respectively, Figure 3a-c). The patients with above-the-median ratio (islets/stroma) had a similar cumulative survival, compared to the patients with below-the-median ratio $(P=0.099$, Figure $3 \mathrm{~d})$.

The patients with above-the-median number of cytotoxic $\mathrm{T}$ cells in the tumor islets and stroma had a significantly better cumulative survival, compared to the patients with below-the-median number of cytotoxic $\mathrm{T}$ cells $(P=0.007$, Figure $4 a)$. There were no significant differences between the above-the-median and below-themedian groups, in regard to the number of cytotoxic $\mathrm{T}$ cells in the tumor islets or tumor stroma, or the ratio of the cell number in the tumor islets versus the cell number in stroma $(\mathrm{P}=0.094,0.287$, and 0.295 , respectively, Figure 4b-d).

In order to determine whether the number of tumorassociated immune cells is correlated to the clinicopathological characteristics, the number of cases with < median cell number was compared with the number of cases with $\geq$ median cell number. We found that the number of macrophages was not correlated with the tumor stage, tumor grade, or lymph node metastasis, except that the adenocarcinomas had more macrophages in the tumor islets and stroma, compared to the non-adenocarcinomas (i.e., squamous and large cell carcinomas) $(\mathrm{P}=$ 0.012 ) (Table 3). However, there were no significant differences when the numbers of macrophages in the tumor islets only or tumor stroma only were compared. The number of mature dendritic cells was less in the tumors of advanced stages (III-IV) or with lymph node metastasis, compared to those of early stages (I-II) or without lymph node metastasis (Table 4). In addition, there were more mature dendritic cells in the tumor islets and stroma of the non-adenocarcinomas, compared to the adenocarcinomas (Table 4). In contrast, the number of cytotoxic $T$ cells was not correlated with the tumor stage, histology, or lymph node metastasis, except that the tumors of poor differentiation had slightly more cytotoxic $\mathrm{T}$ cells in the tumor islets (Table 5 ).

In order to determine whether the number of tumorassociated immune cells is independently associated with patient's survival time, the multivariate Cox proportional hazards analysis was used. The tumor stage, histology, grade and lymph node metastasis were included in the multivariate analysis along with the cell numbers. We found that only the macrophage numbers in the tumor islets or tumor stroma were independent predictors of patient's survival time ( $\mathrm{P}=0.028$ or 0.002 , respectively). The numbers of mature dendritic cells or cytotoxic $\mathrm{T}$ cells were not independent prognostic factors (Table 6).

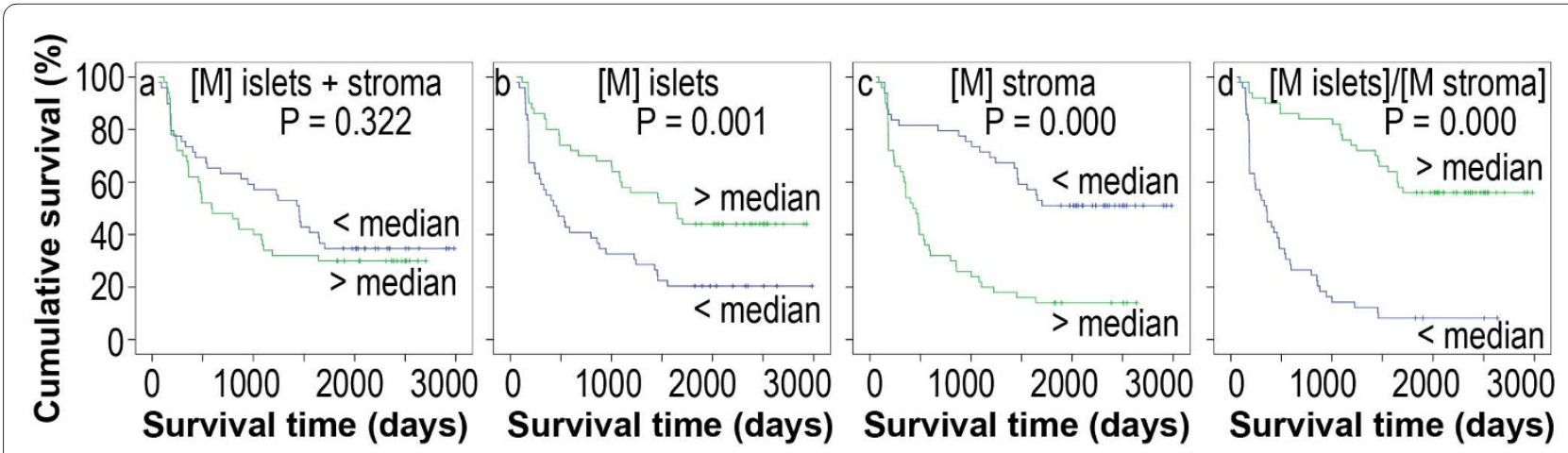

Figure 2 Kaplan-Meier survival curves demonstrate macrophage number or ratio in correlation to survival. [M] represents the macrophage number in the tumor islets and stroma (a), tumor islets (b), and tumor stroma (c). (d) The ratio of the macrophage number in the tumor islets "[M islets]" versus the macrophage number in the tumor stroma "[M stroma]". 


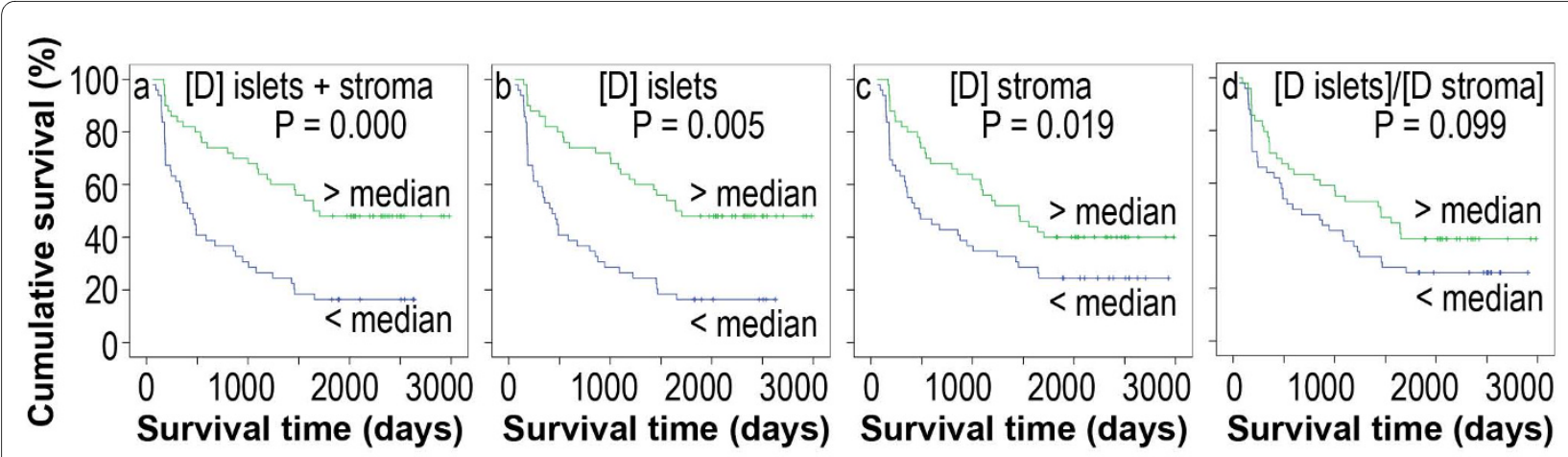

Figure 3 Kaplan-Meier survival curves demonstrate mature dendritic cell number or ratio in correlation to survival. [D] represents the mature dendritic cell number in the tumor islets and stroma (a), tumor islets (b), and tumor stroma (c). (d) The ratio of the mature dendritic cell number in the tumor islets "[D islets]" versus the mature dendritic cell number in the tumor stroma "[D stroma]".

\section{Discussion}

Macrophage is a major component of inflammatory infiltrate of tumors $[8,9]$. Studies on the tumor-associated macrophages (TAMs) in non-small cell lung cancer have reported controversial results. For example, Chen et al reported that the TAMs are negatively associated with survival in the NSCLC patients [10]. Toomey et al found that there is no association between the macrophage number and prognosis of NSCLC [11]. On the other hand, Welsh et al found that the macrophage density in the tumor islets is positively associated with patient's survival [12]. Our previous study showed that the macrophage number in the tumor islets is positively associated with survival, whereas the macrophage number in the tumor stroma is negatively associated with survival [6]. In this study, we again confirmed our previous findings. In addition, we found that the total number of macrophages in both the tumor islets and stroma does not predict prognosis. This may be due to the fact that the macrophage number in the tumor islets is positively associated with survival, whereas the macrophage num- ber in the tumor stroma is negatively associated with survival. Therefore, the positive and negative associations antagonize each other and reduce the net predictive value when the two macrophage pools are counted together. On the other hand, the ratio of macrophage number in the tumor islets versus the macrophage number in the tumor stroma appears to better predict the cumulative survival in the Kaplan-Meier survival curves and univariate analysis (Figure 2d). However, this ratio is not an independent predictor of patient's survival in the multivariate analysis (Table 6). We speculate that this is because some clinicopathological characteristics may affect the distribution of the ratio and thus its statistic significance in the multivariate analysis. For example, the overall macrophage number per high-power field was increased in the adenocarcinomas, which may have an effect on the predictive value of macrophage ratio in the tumor islets/ stroma. The puzzle of why the macrophages in the tumor islets are good for prognosis but the macrophages in the tumor stroma are bad for prognosis may be solved by investigating microlocalization of the M1 and M2 forms
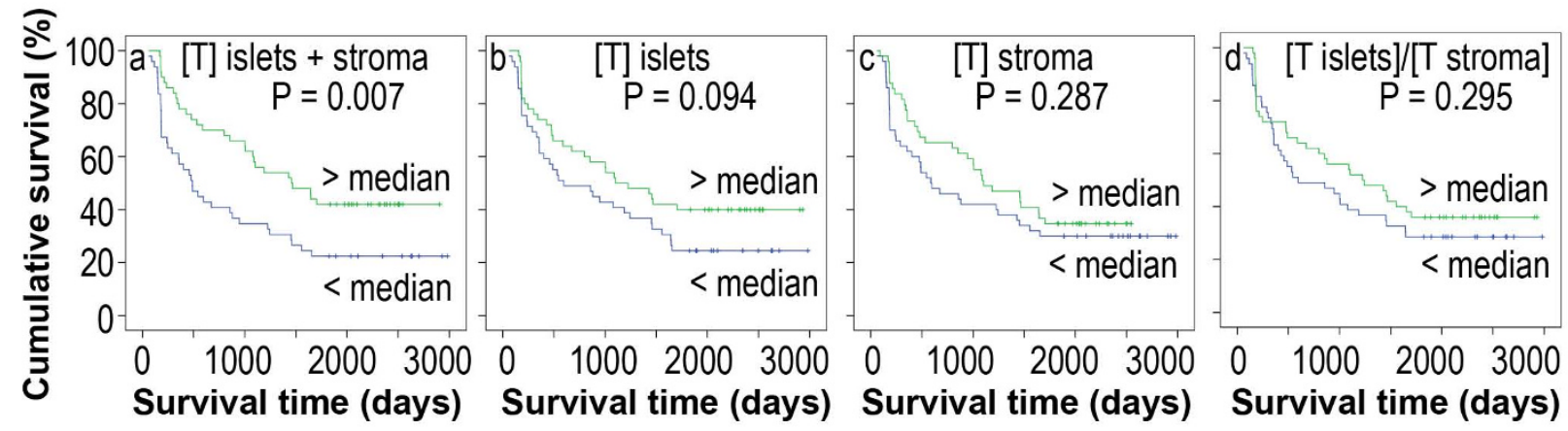

Figure 4 Kaplan-Meier survival curves demonstrate cytotoxic T cell number or ratio in correlation to survival. [T] represents the cytotoxic $T$ cell number in the tumor islets and stroma (a), tumor islets (b), and tumor stroma (c). (d) The ratio of the cytotoxic T cell number in the tumor islets "[T islets]" versus the cytotoxic T cell number in the tumor stroma "[T stroma]". 
Table 3: Correlation between the number of macrophages and clinicopathological characteristics of patients

\begin{tabular}{|c|c|c|c|c|c|c|c|c|c|}
\hline \multirow[t]{2}{*}{ Variable } & \multicolumn{3}{|c|}{ Islets + Stroma } & \multicolumn{3}{|c|}{ Islets } & \multicolumn{3}{|c|}{ Stroma } \\
\hline & $<$ median & $\geq$ median & $\mathbf{P}$ & $<$ median & $\geq$ median & $\mathbf{P}$ & $<$ median & $\geq$ median & $\mathbf{P}$ \\
\hline \multicolumn{10}{|l|}{ Tumor stage: } \\
\hline$|-I|$ & 27 & 28 & 0.929 & 24 & 31 & 0.228 & 31 & 24 & 0.158 \\
\hline III-IV & 22 & 22 & & 25 & 19 & & 18 & 26 & \\
\hline \multicolumn{10}{|l|}{ Histology } \\
\hline Adenocarcinoma & 16 & 29 & 0.012 & 19 & 26 & 0.228 & 19 & 26 & 0.228 \\
\hline Non-adenocarcinoma & 33 & 21 & & 30 & 24 & & 30 & 24 & \\
\hline \multicolumn{10}{|l|}{ Tumor grade } \\
\hline $\begin{array}{l}\text { Well to moderate } \\
\text { differentiation }\end{array}$ & 26 & 24 & 0.646 & 26 & 24 & 0.248 & 26 & 24 & 0.495 \\
\hline Poor differentiation & 14 & 16 & & 11 & 19 & & 13 & 17 & \\
\hline \multicolumn{10}{|l|}{ Lymph node metastasis } \\
\hline No & 28 & 31 & 0.624 & 25 & 34 & 0.103 & 33 & 26 & 0.153 \\
\hline Yes & 21 & 19 & & 24 & 16 & & 16 & 24 & \\
\hline
\end{tabular}

of TAMs. The M1 macrophages have anti-tumor functions, whereas the M2 macrophages contain pro-tumor functions $[13,14]$. A recent study demonstrated that $70 \%$ of macrophages in the tumor islets are the M1 macrophages in the NSCLC patients with extended survival [15]. We recently found that about $85 \%$ of the macrophages in the tumor stroma are the $\mathrm{M} 2$ macrophages in the NSCLC patients with an average of 1-year survival (Ma, et al., unpublished observation).

The density of tumor-infiltrating mature dendritic cells has been found to be a better predictor of clinical outcome than other parameters in a recent study [16]. Our results are consistent with this report. The predictive value of the numbers of mature dendritic cells is only significant in the univariate analysis but not in the multivariate analysis. This implies that we need to be cautious in using the number of mature dendritic cells to predict the patient's outcome.

The number of CD8+ $\mathrm{T}$ cells in the tumor islets is found to be positively associated with survival time in patients with the stage IV NSCLC [17]. Our study shows the same trend but fails to reach any statistical significance (Figure $4 \mathrm{~b}, \mathrm{P}=0.094$ ). We reason that this is because our patient population $(\mathrm{N}=99)$ is smaller than that study's patient population $(\mathrm{N}=199)$ [17]. Both studies showed that the number of cytotoxic $\mathrm{T}$ cells in the tumor stroma is not associated with patient's survival time. In our study, we found that the total number of cytotoxic $\mathrm{T}$ cells in both the tumor islets and stroma is positively associated with patient's survival time in the univariate analysis but not in the multivariate analysis.
This suggests that the clinical significance of counting the number of cytotoxic $\mathrm{T}$ cells is limited, compared to counting the number of macrophages in the tumor islets or stroma. The observed differences among the three immune cells may be caused by the differences in their biological functions. Macrophages not only can serve as antigen-presenting cells (like mature dendritic cells), but also can serve as cytotoxic cells (like cytotoxic $\mathrm{T}$ cells) through releasing reactive oxygen/nitrogen intermediates and TNF $\alpha$ to kill the nearby tumor cells [18].

In the present study, the 5-year survival rate is $44 \%$ for the patients without lymph node metastasis and $15 \%$ for the patients with lymph node metastasis (Table 1), the difference of which is very significant $\left(P=0.002, X^{2}\right.$ analysis). However, it is surprising that the status of lymph node metastasis is not associated with patient's survival in a multivariate Cox proportional hazards model analysis (Table 6). Other studies have shown that lymph node metastasis is an independent prognostic factor in multivariate analysis in patients with NSCLC $[19,20]$. We speculate that the main reason for this discrepancy is that the sample size in our series is not big enough to reach statistical significance in the multivariate analysis. This speculation may also be applied to the association of the density of mature dentritic cells or cytotoxic T cells with the survival in the multivariate analysis, because it is possible that these immune parameters would reach statistical significance in a bigger cohort of patients.

The limitation of this study is that each immune cell type is identified by a single marker. CD68, CD83 and CD8 are widely used to identify macrophages, mature dendritic cells and cytotoxic $\mathrm{T}$ cells, respectively 
Table 4: Correlation between the number of mature dendritic cells and clinicopathological characteristics of patients

\begin{tabular}{|c|c|c|c|c|c|c|c|c|c|}
\hline \multirow[t]{2}{*}{ Variable } & \multicolumn{3}{|c|}{ Islets + Stroma } & \multicolumn{3}{|c|}{ Islets } & \multicolumn{3}{|c|}{ Stroma } \\
\hline & $<$ median & $\geq$ median & $\mathbf{P}$ & $<$ median & $\geq$ median & $\mathbf{P}$ & $<$ median & $\geq$ median & $\mathbf{P}$ \\
\hline \multicolumn{10}{|l|}{ Tumor stage: } \\
\hline$|-I|$ & 21 & 34 & 0.012 & 23 & 32 & 0.107 & 22 & 33 & 0.044 \\
\hline III-IV & 28 & 16 & & 26 & 18 & & 27 & 17 & \\
\hline \multicolumn{10}{|l|}{ Histology } \\
\hline Adenocarcinoma & 30 & 15 & 0.002 & 27 & 18 & 0.070 & 27 & 18 & 0.070 \\
\hline $\begin{array}{l}\text { Non- } \\
\text { adenocarcinoma }\end{array}$ & 19 & 35 & & 22 & 32 & & 22 & 32 & \\
\hline \multicolumn{10}{|l|}{ Tumor grade } \\
\hline $\begin{array}{l}\text { Well to moderate } \\
\text { differentiation }\end{array}$ & 21 & 29 & 0.861 & 23 & 27 & 0.647 & 26 & 24 & 0.066 \\
\hline $\begin{array}{l}\text { Poor } \\
\text { differentiation }\end{array}$ & 12 & 18 & & 12 & 18 & & 9 & 21 & \\
\hline \multicolumn{10}{|l|}{$\begin{array}{l}\text { Lymph node } \\
\text { metastasis }\end{array}$} \\
\hline No & 23 & 36 & 0.014 & 24 & 35 & 0.041 & 25 & 34 & 0.103 \\
\hline Yes & 26 & 14 & & 25 & 15 & & 24 & 16 & \\
\hline
\end{tabular}

[15,17,21-25]. However, these markers are also expressed by other cell types. For example, CD68 has been found in immature CD1a-positive dendritic cells [26,27]. CD83 is also expressed by other cell types such as B lymphocytes [28]. A better marker for mature dendritic cells is DCLamp (CD208, using rat IgG2a antibodies, clone
SR1010.E1, from Schering-Plough, Kenilworth, NJ) for paraffin-embedded tissue sections [16]. Although most tumor-infiltrating CD8 + T cells are cytotoxic T cells [25], some CD8+ T cells are regulatory $\mathrm{T}$ cells [29]. Therefore, it is possible that a portion of the immune cells identified by these markers are not the named immune cells (i.e.,

Table 5: Correlation between the number of cytotoxic $\mathbf{T}$ cells and clinicopathological characteristics of patients

\begin{tabular}{|c|c|c|c|c|c|c|c|c|c|}
\hline \multirow[t]{2}{*}{ Variable } & \multicolumn{3}{|c|}{ Islets + Stroma } & \multicolumn{3}{|c|}{ Islets } & \multicolumn{3}{|c|}{ Stroma } \\
\hline & $<$ median & $\geq$ median & $\mathbf{P}$ & $<$ median & $\geq$ median & $\mathbf{P}$ & $<$ median & $\geq$ median & $\mathbf{P}$ \\
\hline \multicolumn{10}{|l|}{ Tumor stage: } \\
\hline$|-| \mid$ & 23 & 32 & 0.107 & 24 & 31 & 0.228 & 27 & 28 & 0.840 \\
\hline III-IV & 26 & 18 & & 25 & 19 & & 23 & 21 & \\
\hline \multicolumn{10}{|l|}{ Histology } \\
\hline Adenocarcinoma & 24 & 21 & 0.547 & 23 & 22 & 0.841 & 24 & 21 & 0.688 \\
\hline $\begin{array}{l}\text { Non- } \\
\text { adenocarcinoma }\end{array}$ & 25 & 29 & & 26 & 28 & & 26 & 28 & \\
\hline \multicolumn{10}{|l|}{ Tumor grade } \\
\hline $\begin{array}{l}\text { Well to moderate } \\
\text { differentiation }\end{array}$ & 26 & 24 & 0.248 & 29 & 21 & 0.040 & 28 & 22 & 0.248 \\
\hline $\begin{array}{l}\text { Poor } \\
\text { differentiation }\end{array}$ & 11 & 19 & & 10 & 20 & & 12 & 18 & \\
\hline \multicolumn{10}{|l|}{$\begin{array}{l}\text { Lymph node } \\
\text { metastasis }\end{array}$} \\
\hline No & 25 & 34 & 0.103 & 27 & 32 & 0.416 & 29 & 30 & 0.838 \\
\hline Yes & 24 & 16 & & 22 & 18 & & 21 & 19 & \\
\hline
\end{tabular}


Table 6: Correlation between the number and microlocalization of immune cells and patient's survival time by a multivariate Cox proportional hazards model analysis

\begin{tabular}{|c|c|c|c|}
\hline Factor & Hazard ratio & 95\% Confidence interval & $\mathbf{P}$ \\
\hline Tumor stage & 6.790 & $1.319-34.952$ & 0.022 \\
\hline Histology & 0.973 & $0.934-1.003$ & 0.116 \\
\hline Tumor grade & 0.208 & $0.076-2.669$ & 0.228 \\
\hline Lymph node metastasis & 0.661 & $0.260-1.679$ & 0.384 \\
\hline Macrophages in islets & 0.909 & $0.834-0.990$ & 0.028 \\
\hline Macrophages in stroma & 1.080 & $1.029-1.133$ & 0.002 \\
\hline $\begin{array}{l}\text { Ratio of islets/stroma of } \\
\text { macrophages }\end{array}$ & 0.970 & $0.847-1.111$ & 0.663 \\
\hline $\begin{array}{l}\text { Mature dendritic cells in islets } \\
\text { and stroma }\end{array}$ & 1.061 & $0.938-1.200$ & 0.350 \\
\hline Mature dendritic cells in islets & 0.922 & $0.841-1.012$ & 0.087 \\
\hline $\begin{array}{l}\text { Mature dendritic cells in } \\
\text { stroma }\end{array}$ & 1.002 & $0.933-1.075$ & 0.963 \\
\hline $\begin{array}{l}\text { CD8+ T cells in islets and } \\
\text { stroma }\end{array}$ & 1.013 & $0.988-1.039$ & 0.311 \\
\hline $\mathrm{CD} 8+\mathrm{T}$ cells in islets & 1.029 & $0.992-1.068$ & 0.125 \\
\hline CD8+ T cells in stroma & 0.978 & $0.934-1.023$ & 0.335 \\
\hline
\end{tabular}

macrophages, mature dendritic cells, and cytotoxic $\mathrm{T}$ cells, respectively).

\section{Conclusions}

This study demonstrates that macrophages, mature dendritic cells, and cytotoxic T cells are present more in the tumor stroma than in the tumor islets in non-small cell lung cancer. Although the number and microlocalization of the three tumor-associated immune cells appear similar, the clinical significance of counting these cells is quite different. The tumor-associated macrophages may be the most important immune cells in NSCLC, because the number of TAMs in the tumor islets or stroma can independently predict patient's survival time.

\section{Competing interests}

The authors declare that they have no competing interests.

\section{Authors' contributions}

FD performed immunohistochemistry, evaluated the stained slides, and performed statistical analysis. LL and GC designed and supervised the collection of data. NY collected the clinicopathological data. QP, SZ, JM, and LM participated in making the slides, evaluation of the stained slides, and data analysis. ZY analyzed and interpreted the data and prepared the tables, figures, and manuscript text. All authors participated in manuscript preparation and approved the final version prior to submission.

\section{Acknowledgements}

$\mathrm{LL}$ is supported by grants from Science and Technology Bureau of Sichuan Province (No. 2006Z09-012, No. 2007SGY018, and No. 2009SZ0152). ZY is supported by grants from the U.S. Army Medical Research and Material Command, Department of Defense (W81XWH-05-1-0567), NIH/NCRR (2P20 RR020152-06), and Louisiana Cancer Research Consortium Fund; this international collaboration is particularly supported by Tulane Framework for Global Health Seed Grant (A47599G1), NIH - Fogarty Center - Dr. Buekens Seed Grant.

\section{Author Details}

1Department of Thoracic and Cardiovascular Surgery, West China Hospital, Sichuan University, Chengdu 610041, China, 2Daping Hospital, the Third Military Medical University, Chongqing City, China, 3The Third People's Hospital of Zigong City, Sichuan Province, China and ${ }^{4}$ Departments of Structural \& Cellular Biology and Orthopaedic Surgery, Tulane Cancer Center, LCRC, Tulane Center for Aging, Tulane Center for Gene Therapy, Tulane University School of Medicine, New Orleans, LA 70112, USA

Received: 3 October 2009 Accepted: 20 May 2010

Published: 20 May 2010

\section{References}

1. Witz IP, Levy-Nissenbaum O: The tumor microenvironment in the postPAGET era. Cancer Lett 2006, 242(1):1-10.

2. Lin A, Schildknecht A, Nguyen LT, Ohashi PS: Dendritic cells integrate signals from the tumor microenvironment to modulate immunity and tumor growth. Immunol Lett 2009.

3. Chen JJ, Lin YC, Yao PL, Yuan A, Chen HY, Shun CT, Tsai MF, Chen CH, Yang PC: Tumor-associated macrophages: the double-edged sword in cancer progression. J Clin Oncol 2005, 23(5):953-964.

4. Loose D, Wiele C Van de: The immune system and cancer. Cancer Biother Radiopharm 2009, 24(3):369-376.

5. Mountain CF: Revisions in the International System for Staging Lung Cancer. Chest 1997, 111(6):1710-1717.

6. Yu N, Pu J, Pu Q, Che G, Zhang S, Liu L: Influence of Tumor Associated Macrophages Distribution on Prognosis of Non-small Cell Lung Cancer. Chin J Clin Thorac Cardiovasc Surg 2009, 16(1):44-47.

7. Travis WD, Brambilla E, Muller-Hermelink HK, Harris CC: World Health Organization Classification of Tumours. Pathology and Genetics of Tumours of the Lung, Pleura, Thymus and Heart. Lyon: IARC Press; 2004.

8. Mantovani A, Bottazzi B, Colotta F, Sozzani S, Ruco L: The origin and function of tumor-associated macrophages. Immunol Today 1992, 13(7):265-270.

9. Balkwill F, Mantovani A: Inflammation and cancer: back to Virchow? Lancet 2001, 357(9255):539-545.

10. Chen JJ, Yao PL, Yuan A, Hong TM, Shun CT, Kuo ML, Lee YC, Yang PC: Upregulation of tumor interleukin-8 expression by infiltrating macrophages: its correlation with tumor angiogenesis and patient 
survival in non-small cell lung cancer. Clin Cancer Res 2003, 9(2):729-737.

11. Toomey D, Smyth G, Condron C, Kelly J, Byrne AM, Kay E, Conroy RM, Broe $P$, Bouchier-Hayes D: Infiltrating immune cells, but not tumour cells, express FasL in non-small cell lung cancer: No association with prognosis identified in 3-year follow-up. Int $J$ Cancer 2003, 103(3):408-412.

12. Welsh TJ, Green RH, Richardson D, Waller DA, O'Byrne KJ, Bradding P: Macrophage and mast-cell invasion of tumor cell islets confers a marked survival advantage in non-small-cell lung cancer. $J$ Clin Oncol 2005, 23(35):8959-8967.

13. Mantovani A, Sica A, Locati M: Macrophage polarization comes of age. Immunity 2005, 23(4):344-346.

14. Mantovani A, Sozzani S, Locati M, Allavena P, Sica A: Macrophage polarization: tumor-associated macrophages as a paradigm for polarized M2 mononuclear phagocytes. Trends Immunol 2002 23(11):549-555.

15. Ohri CM, Shikotra A, Green RH, Waller DA, Bradding P: Macrophages within NSCLC tumour islets are predominantly of a cytotoxic M1 phenotype associated with extended survival. Eur Respir J 2009, 33(1):118-126.

16. Dieu-Nosjean MC, Antoine M, Danel C, Heudes D, Wislez M, Poulot V, Rabbe N, Laurans L, Tartour E, de Chaisemartin L, et al.: Long-term survival for patients with non-small-cell lung cancer with intratumoral lymphoid structures. J Clin Oncol 2008, 26(27):4410-4417.

17. Kawai O, Ishii G, Kubota K, Murata Y, Naito Y, Mizuno T, Aokage K, Saijo N, Nishiwaki Y, Gemma A, et al:: Predominant infiltration of macrophages and CD8(+) T Cells in cancer nests is a significant predictor of survival in stage IV nonsmall cell lung cancer. Cancer 2008, 113(6):1387-1395.

18. Mantovani A, Sica A, Locati M: New vistas on macrophage differentiation and activation. Eur J Immunol 2007, 37(1):14-16.

19. Fukui T, Mori S, Yokoi K, Mitsudomi T: Significance of the number of positive lymph nodes in resected non-small cell lung cancer. J Thorac Oncol 2006, 1(2):120-125.

20. Ueda K, Kaneda Y, Sakano H, Tanaka T, Hayashi M, Li TS, Hamano K Independent predictive value of the overall number of metastatic N1 and N2 stations in lung cancer. Jpn J Thorac Cardiovasc Surg 2003, 51(7):297-301.

21. Al-Shibli K, Al-Saad S, Donnem T, Persson M, Bremnes RM, Busund LT: The prognostic value of intraepithelial and stromal innate immune system cells in non-small cell lung carcinoma. Histopathology 2009, 55(3):301-312.

22. Kim DW, Min HS, Lee KH, Kim YJ, Oh DY, Jeon YK, Lee SH, Im SA, Chung $\mathrm{DH}$, Kim YT, et al: High tumour islet macrophage infiltration correlates with improved patient survival but not with EGFR mutations, gene copy number or protein expression in resected non-small cell lung cancer. Br J Cancer 2008, 98(6):1118-1124.

23. van Cruijsen H, Ruiz MG, Valk P Van der, de Gruijl TD, Giaccone G: Tissue micro array analysis of ganglioside $\mathrm{N}$-glycolyl GM3 expression and signal transducer and activator of transcription (STAT)-3 activation in relation to dendritic cell infiltration and microvessel density in nonsmall cell lung cancer. BMC Cancer 2009, 9:180.

24. Bergeron A, El-Hage F, Kambouchner M, Lecossier D, Tazi A: Characterisation of dendritic cell subsets in lung cancer microenvironments. Eur Respir J 2006, 28(6):1170-1177.

25. Hiraoka K, Miyamoto M, Cho Y, Suzuoki M, Oshikiri T, Nakakubo Y, Itoh T, Ohbuchi T, Kondo S, Katoh H: Concurrent infiltration by CD8+ T cells and CD4+ T cells is a favourable prognostic factor in non-small-cell lung carcinoma. Br J Cancer 2006, 94(2):275-280.

26. Geissmann F, Dieu-Nosjean MC, Dezutter C, Valladeau J, Kayal S, Leborgne M, Brousse N, Saeland S, Davoust J: Accumulation of immature Langerhans cells in human lymph nodes draining chronically inflamed skin. J Exp Med 2002, 196(4):417-430.

27. Caux C, Vanbervliet B, Massacrier C, Dezutter-Dambuyant C, de Saint-Vis B, Jacquet C, Yoneda K, Imamura S, Schmitt D, Banchereau J: CD34+ hematopoietic progenitors from human cord blood differentiate along two independent dendritic cell pathways in response to GM-CSF+TNF alpha. J Exp Med 1996, 184(2):695-706

28. Kretschmer B, Luthje K, Schneider S, Fleischer B, Breloer M: Engagement of CD83 on B cells modulates B cell function in vivo. J Immunol 2009, 182(5):2827-2834
29. Karagoz B, Bilgi O, Gumus M, Erikci AA, Sayan O, Turken O, Kandemir EG, Ozturk A, Yaylaci M: CD8+CD28- cells and CD4+CD25+ regulatory T cells in the peripheral blood of advanced stage lung cancer patients. Med Oncol 2009.

\section{Pre-publication history}

The pre-publication history for this paper can be accessed here: http://www.biomedcentral.com/1471-2407/10/220/prepub

doi: $10.1186 / 1471-2407-10-220$

Cite this article as: Dai et al., The number and microlocalization of tumorassociated immune cells are associated with patient's survival time in nonsmall cell lung cancer BMC Cancer 2010, 10:220

\section{Submit your next manuscript to BioMed Central and take full advantage of:}

- Convenient online submission

- Thorough peer review

- No space constraints or color figure charges

- Immediate publication on acceptance

- Inclusion in PubMed, CAS, Scopus and Google Scholar

- Research which is freely available for redistribution

Submit your manuscript at www.biomedcentral.com/submit
C Biomed Central 